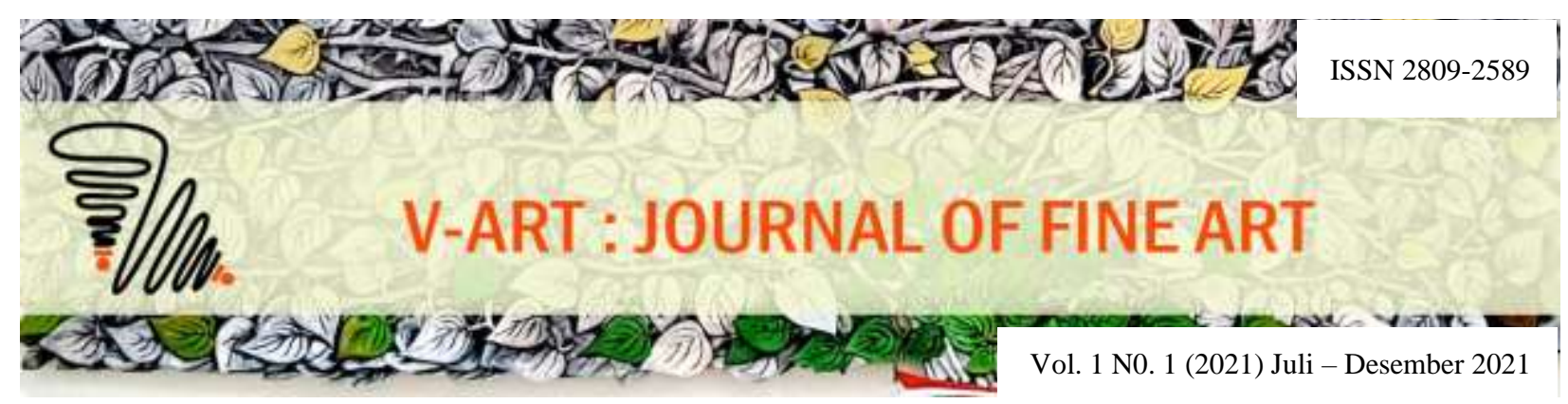

\title{
Estetika Karya Lukis Afianto Arifin
}

\author{
Selvina Rahmi ${ }^{1}$, Suryanti ${ }^{2}$, dan Miswar ${ }^{3}$ \\ Program Studi Seni Murni, Fakultas Seni Rupa dan Desain \\ Institut Seni Indonesia Padangpanjang \\ Jalan Bahder Johan No. 35, Kelurahan Guguk Malintang, Padangpanjang, 27128 \\ Sumatera Barat, Indonesia \\ Email: selvinarahmi123@gmail.com,yantisur688@gmail.com,dan miswarbakar@gmail.com
}

\begin{abstract}
Abstrak
Penelitian ini membahas tentang kecenderungan Afianto Arifin yang masih bertahan dengan gaya naturalisme yang kental di tengah-tengah gencarnya seni rupa kontemporer. Penelitian ini juga membahas tentang perjalanan berkesenian, faktor yang melatarbelakangi sikap berkaryanya, dan konsep estetika yang terdapat dalam lukisannya. Untuk menjawab permasalahan tersebut, digunakan metode penelitian kualitatif yang meliputi observasi, wawancara, dan studi pustaka. Penelitian dilakukan di daerah Kota Bukittinggi dan Kabupaten Padang Pariaman, provinsi Sumatera Barat. Berdasarkan hasil penelitian, awal karier berkesenian Afianto Arifin dimulai di Jakarta. Selain melukis, Arifin juga mendapat proyek membuat patung dan relief. Setelah itu, Arifin benar-benar tekun membuat lukisan. Arifin cenderung mengangkat objek pemandangan alam dan kecantikan wanita. Ide penciptaan karya lukis Arifin dipengaruhi oleh faktor kesenimanan dan faktor adat istiadat yang ada di daerah asalnya, yakni Bukittinggi. Konsep estetika yang terdapat dalam karya lukis Arifin dibahas melalui sudut pandang gaya-gaya seni, struktur seni, serta interaksi media dan makna. Arifin merupakan pribadi yang cenderung tidak ingin diekspos dan tidak suka melihat pameran, hal tersebut membuat Arifin tetap berpegang teguh terhadap idealisme-nya sendiri dan mempengaruhi gaya berkeseniannya hingga sampai saat sekarang.
\end{abstract}

Kata Kunci: Afianto Arifin; estetika; karya lukis.

\begin{abstract}
This study discusses Afianto Arifin's tendency to persist with a strong naturalism style during the incessant contemporary art. This study also discusses the journey of art, the factors behind his work attitude, and the aesthetic concepts contained in his paintings. To answer these problems, qualitative research methods are used which include observation, interviews, and literature study. The research was conducted in the City of Bukittinggi and Padang Pariaman district, West Sumatra province. Based on the research results, the beginning of Afianto Arifin's artistic career began in Jakarta. Apart from painting, Arifin also got a project to make sculptures and reliefs. After that, Arifin was diligent in making paintings. Arifin tends to raise objects of natural scenery and women's beauty. The idea of creating Arifin's paintings was influenced by artistic factors and cultural factors in his native area, namely Bukittinggi. The aesthetic concepts contained in Arifin's paintings are discussed from the point of view of art styles, art structures, as well as the interaction of media and meaning. Arifin is a person who tends to not want to be exposed and does not like to see exhibitions, this makes Arifin stick to his ideals and influences his artistic style until now.
\end{abstract}

Keywords: Afianto Arifin; aesthetics; paintings. 


\section{PENDAHULUAN}

Afianto Arifin yang biasa dipanggil Arifin merupakan seniman lukis yang lahir di Bukittinggi pada tanggal 22 Desember 1943. Afianto Arifin sudah menampakkan bakat di bidang seni rupa semenjak duduk di bangku SMP, terbukti sempat mendapat tawaran dari pemerintah Belanda untuk melanjutkan pendidikan ke sekolah seni di Moscow, Rusia, namun karena saat itu situasi politik sedang panas dan PKI sedang bergejolak, maka keberangkatan pun dibatalkan. Bakat adalah potensi kemampuan khas yang dimiliki oleh seseorang, yang didapatkan berkat keturunannya (A.A.M. Djelantik, 2004). Secara biologis, keturunan itu ditentukan oleh unsur-unsur genetik, yang disebut gen yang terletak pada kromosome dalam masing-masing sel dari tubuh makhluk. Arifin bakat yang dimiliki bukanlah berasal dari keturunan, melainkan kemampuan yang dimiliki sejak kecil.

Afianto Arifin merupakan pelukis senior di Sumatera Barat yang terinspirasi dengan gaya modern khususnya gaya naturalis. Selama karier berkeseniannya, Arifin seakan tidak terpengaruh dengan perubahan gaya yang berkembang, Arifin tetap konsisten dengan gayanya. Karya yang muncul di zaman sekarang tidak lepas pengaruh naturalis dan realis. Bagi Arifin, menguasai ilmu naturalis adalah pintu untuk mempermudah penguasaan terhadap gaya yang muncul setelahnya.

Menurut Yunis Muler, sosok Afianto Arifin adalah sosok yang terus berkesenian tanpa henti, mendalam dan matang dalam berkarya. Karya Arifin tidak kalah dengan karya kontemporer, jarang seniman pada zaman sekarang melukis tanpa henti seperti dirinya. Arifin seakan tak kenal waktu, ia akan berhenti melukis ketika hendak shalat, makan dan tidur. Ke depannya, karya-karya Arifin akan dicari dan bernilai lebih (wawancara tanggal 24 Februari 2014). Arifin merupakan pribadi yang tidak terlalu aktif berpameran ataupun mengikuti event pameran. Hal tersebut dikarenakan Arifin memang tidak mau prinsip berkeseniannya terpengaruh oleh gaya lain. Adapun beberapa pameran yang diadakan belakangan, diselenggarakan oleh pihak yang memang menjadi kolektor pribadi Arifin (wawancara bersama Arifin tanggal 22 Februari 2014). Karya-karyanya selalu bercerita tentang keindahan alam Minangkabau dan figur yang dihadirkan kebanyakan adalah sosok wanita. Bentangan alam yang dilukiskan tidak dilukis langsung oleh Arifin, berbanding terbalik dengan konsep naturalis yang menangkap objek secara langsung, akan tetapi Arifin merekayasa ulang bentuk- bentuk alamnya sendiri, termasuk warna dan suasananya ke dalam bidang kanvas.

Penelitian tentang Afianto Arifin dan karya seninya di Sumatera Barat menjadi menarik untuk ditelusuri, beberapa alasan di antaranya: 1) Karya lukis Afianto Arifin sangat menjunjung tinggi nilai kedaerahan, terbukti dari awal berkesenian hingga sekarang, Arifin terus konsisten mengangkat tema alam Minangkabau sebagai ide penciptaannya. 2) Lukisan Arifin identik dengan gaya naturalis, padahal seni rupa yang berkembang zaman sekarang adalah seni rupa kontemporer. 3) Hingga usia senjanya, Arifin masih terus aktif berkarya dan banyak memberikan jasa bagi perkembangan seni rupa Sumatera Barat, tapi tidak terlalu dikenal. Dari uraian di atas muncul keterkaitan mengangkat bagaimana perjalanan karier berkesenian Afianto Arifin, faktor-faktor yang mempengaruhi Afianto Arifin dalam melukis, serta konsep estetika yang terdapat dalam karya lukisnya dalam sebuah penelitian. Penulis mengisyaratkan, hasil penelitian ini akan memberikan manfaat sepadan tentang apa dan mengapa Afianto Arifin diangkat menjadi objek penelitian terhadap perkembangan seni rupa Sumatera Barat. Alasan itu pulalah yang mendorong penulis untuk merumuskan penelitian ini dengan judul "Estetika Karya Lukis Afianto Arifin"

\section{KAJIAN TEORI}

Sejalan dengan hal tersebut, untuk memahami sosok seniman dengan mengetahui biografinya itu sendiri, perlu sekiranya melakukan pendekatan di bidangbidang tertentu. Bersamaan dengan hal tersebut, penelitian historial ini mengkaji biografi seorang seniman seperti yang diungkapkan oleh (Kartodirjo, 1993:41), perspektif historis melihat masa kini tidak terlepas dari masa lampau dan identitasnya. Sebaliknya, gambaran masa lampau ditentukan oleh pandangan masa kini. Perspektif historis mempunyai dua dimensi: (1) aspek masa kini; dan (2) aspek masa lampau.

Ada empat istilah dalam diri seorang seniman, yakni profesional terintegrasi, maverick (inkonvensional), seniman rakyat, dan seniman naif. Becker menyatakan bahwa karya yang dikerjakan orang-orang berbeda menurut sifat partisipasi mereka dalam dunia seni. Tetapi itu tidak berarti bahwa hal tersebut merupakan karakter dari partisipasi mereka dalam dunia seni. Istilah relasional tersebut tidak mendeskripsikan orang, tetapi lebih bagaimana orang-orang berpihak dalam hubungan dengan dunia seni yang terorganisir (Becker, 1982). Berdasarkan pembagian karakter dalam diri seniman yang di kemukakan oleh Becker 
tersebut, peneliti nantinya hanya akan menggunakan dua istilah yang sesuai dengan kepribadian Arifin, yakni profesional terintegrasi dan seniman naif. Bersamaan dengan hal tersebut, penelitian ini juga menggunakan pendekatan historial untuk mengkaji biografi seorang seniman. Perspektif historis melihat masa kini tidak terlepas dari masa lampau dan identitasnya. Sebaliknya, gambaran masa lampau ditentukan oleh pandangan masa kini. Perspektif historis mempunyai dua dimensi: (1) aspek masa kini; dan (2) aspek masa lampau (Kartodirjo, 1993).

Kajian ini tidak akan lengkap tanpa adanya pendekatan estetika seperti yang meliputi gaya seni, struktur seni, serta interaksi media dan makna (Feldman, Edmund, 1967). Teori ini digunakan sebagai pisau pembedah dalam menganalisis karya lukis Afianto Arifin.

\section{METODE PENELITIAN}

Adapun metode yang digunakan dalam penelitian ini meliputi:

1. Menentukan Lokasi (Wilayah dan Tempat) dan Topik Penelitian.

Sebelum menentukan topik yang akan dibahas, terlebih dahulu penulis harus menentukan lokasi di mana keberadaan objek yang akan diteliti. Di sini, penulis akan meneliti di kota Bukittinggi, khususnya belakang pasar Banto, sebuah tempat di mana kediaman serta studio Arifin, serta di Padang Pariaman ke tempat kediaman Evelyna Dianita yang merupakan anak Arifin.

\section{Pengumpulan Data}

a. Studi Kepustakaan

Studi kepustakaan dilakukan guna mendapatkan bahan-bahan yang akan mendukung penulisan, bahan tersebut berupa buku-buku, skripsi, tesis, serta sumber-sumber lainnya seperti katalog, majalah seni yang didapat pada Pustaka ISI Padangpanjang, dan pada saat menghadiri event pameran.

\section{b. Studi Lapangan}

Sehubungan dengan pengumpulan data melalui studi lapangan, maka dilakukan kegiatan dalam bentuk sebagai berikut:

\section{1) Observasi}

Penelitian ini adalah penelitian tentang seni rupa, maka sangat diperlukan observasi atau menyaksikan langsung pameran atau sebuah event tertentu. Hal ini untuk membantu proses mengenal dan mengasah kemampuan untuk memilah-milah karya lukisan itu sendiri, apalagi dalam pembuatan laporan penelitian memerlukan data visual, maka untuk mendapatkan data pendukung tentang Lukisan Afianto Arifin dilakukan perekaman dengan menggunakan alat rekam kamera video dan kamera foto.

2) Wawancara

Guna mengetahui berbagai hal yang berkaitan dengan penelitian tentang Lukisan Afianto Arifin, dilakukan wawancara dengan cara mengajukan berbagai pernyataan yang berbentuk tanya jawab kepada Afianto Arifin dan beberapa informan lain. Semua hasil wawancara tersebut dicatat secara langsung dalam buku catatan. Selain itu, direkam secara auditif dengan menggunakan tape recorder, agar dapat didengar kembali pada waktu mengolah data.

c. Pengolahan Data

Setelah data yang berkaitan dengan Lukisan Afianto Arifin terkumpul, langkah berikutnya adalah upaya pengelompokan data atau penyeleksian data sesuai dengan kelompok permasalahan. Data tersebut merupakan data primer, yakni data yang diperoleh dari hasil wawancara terhadap Afianto Arifin dan orang terdekatnya. Di samping data sekunder yaitu data yang didapat dari sumber tertulis, baik tentang lukisan, maupun tentang permasalahan lainnya yang berkaitan dengan penelitian ini.

Selanjutnya, dilakukan proses penganalisaan terhadap data yang dipilih tersebut menggunakan teori-teori yang sesuai dengan rumusan dan tujuan penelitian. Hasil dari analisis ini kemudian disusun dalam laporan penelitian dalam bentuk skripsi di bawah bimbingan langsung dosen pembimbing. Pembuatan atau penyusunan laporan merupakan tahap akhir dari proses penelitian, untuk menyampaikan dengan pernyataan-pernyataan ilmiah berdasarkan data-data yang diperoleh ke dalam bentuk tulisan yang dapat dipertanggungjawabkan.

\section{Populasi dan Sampel}

a. Populasi

Populasi adalah keseluruhan obyek penelitian. Apabila seseorang ingin meneliti semua elemen yang ada dalam wilayah penelitian, maka penelitiannya merupakan penelitian populasi (Arikunto, 1993:102).

Adapun yang akan menjadi populasi dalam penelitian tentang Lukisan Afianto Arifin ini adalah keseluruhan karya-karya yang dihasilkan dari tahun 1976 sampai tahun 2014. Tema-tema dari keseluruhan karya tersebut adalah landscape, potrait, kehidupan sosial antara manusia dan alam, dan nude.

b. Sampel

Sampel adalah sebagian atau wakil populasi yang diteliti (Arikunto, 1993:102). Sampel juga merupakan 
bagian dari populasi yang menjadi objek penelitian (sampel sendiri secara harfiah berarti contoh). Oleh karena itu, sampel harus dilihat sebagai pendugaan terhadap populasi dan bukan populasi itu sendiri (Prasetyo, 2005:119).

Ada begitu banyak masalah yang dapat diteliti dari Afianto Arifin, namun mengingat adanya keterbatasan waktu, tenaga dan biaya, maka penelitian ini akan menggunakan sampel berupa karya-karya Afianto Arifin yang akan diambil secara acak sesuai kebutuhan (sesuai tema lukisan), tetapi masih dalam ruang lingkup dari tahun 1976 sampai 2014.

\section{HASIL DAN PEMBAHASAN}

Seni merupakan usaha manusia untuk menciptakan bentuk-bentuk yang menyenangkan. Bentuk yang menyenangkan dalam arti bentuk yang dapat membingkai perasaan keindahan dan perasaan keindahan itu dapat terpuaskan apabila dapat menangkap harmoni atau satu kesatuan dari bentuk yang disajikan (Read, 1958). Ditambahkan oleh Langer, seni merupakan simbol dari perasaan. Seni merupakan kreasi bentuk simbolis dari perasaan manusia. Bentuk-bentuk simbolis yang mengalami transformasi yang merupakan universalisasi dari pengalaman, dan bukan merupakan terjemahan dari pengalaman tertentu dalam karya seninya melainkan formasi pengalaman emosionalnya yang bukan dari pikirannya semata (Kartika, 2004).

Terkait dengan teori yang dijabarkan di atas bahwa seni selain ungkapan pikiran dan perasaan, seni juga sebagai alat komunikasi antara seniman dengan penghayat melalui karya seni, maka sekiranya dapat dipahami bahwa Arifin sangat memahami akan fungsi-fungsi seni di atas, sehingga Arifin mencoba mengomunikasikan pesan-pesan yang ingin disampaikan ke dalam bentuk karya. Alam Minangkabau yang indah, potret wanita bersahaja Minangkabau yang disebut dengan bundo kanduang, kehidupan bermasyarakat rakyat Minang, legenda dan mitos yang ada di suku Minangkabau terkonsep dalam karya-karya Arifin melalui bahasa visual dan tekniknya tersendiri.

\section{Gaya-Gaya dalam Karya Seni Lukis Afianto Arifin}

Mengkaji gaya-gaya seni merupakan salah satu cara mengukur tingkat keberhasilan, pencapaian dan kematangan seorang seniman dalam berkarya seni. Untuk itu Feldman menawarkan beberapa pendekatan dari segi gaya yang dapat dijadikan sebagai pisau bedah dalam menelaah karya seni lukis Afianto Arifin, yakni a). Gaya ketepatan objektif, b). Gaya susunan formal, c). Gaya emosi, dan d). Gaya fantasi (Feldman, 1967).

\section{a. Gaya Ketepatan Objektif}

Feldman menyebutkan bahwa gaya ketetapan objektif semata-mata berhubungan dengan lukisan, gambar, dan patung sejak mereka (lukisan, gambar dan patung itu) merupakan karya-karya seni yang sering memiliki hubungan yang erat dengan tiruan tentang fenomena visual (Feldman, 1967: 6). Hal ini bisa diterjemahkan bahwa gaya ketetapan objektif adalah gaya yang esensinya meniru atau memindahkan objek alam ke dalam bentuk lukisan. Hal ini sangat dekat dengan gaya berkesenian Arifin yang 'naturalis' yakni karya lukisnya tak jauh dari persoalan bentuk alam dan kehidupan sehari-hari manusianya. Namun letak perbedaannya adalah persoalan teknis, di mana konsep naturalis sejatinya adalah memilih dan memindahkan objek yang indah-indah saja langsung di alam, sedangkan bagi Arifin yang merupakan seorang pelukis studio, ia memiliki konsep tersendiri tentang naturalis, yakni objek alam yang telah diamati divisualkan lewat kanvas di studionya tanpa mengurangi kaidah-kaidah naturalis itu sendiri.

Feldman juga menjelaskan bahwa alasan lain bagi daya tarik dalam peniruan gambar-gambar terletak pada hubungan artistik dengan penceriteraan (Feldman, 1967: 11). Dalam karya lukisan Arifin, mayoritas karyanya mengangkat tema alam, manusia dan cerita fiksi. Bentuk-bentuk yang dihadirkan kembali dalam karya lukisnya adalah hasil ketajaman imajinasinya atas objek yang telah Arifin amati. Setelah Arifin terjun mengamati objeknya secara langsung, selanjutnya Arifin akan menumpahkan objek yang telah diamati tersebut ke bidang kanvas di studionya sendiri dengan mengandalkan bentuk yang telah direkam di alam. Sebagai contoh pada karya Arifin yang berjudul "Sungai di Tengah Hutan", meskipun Arifin tidak melukiskan pemandangan hutannya secara langsung, namun ketepatan bentuk alam, pepohonan dan aliran air sungainya hampir mendekati dengan objek sebenarnya (realis) dan lukisan tersebut merupakan hasil imajinasinya sendiri terhadap alam yang telah diamati sebelumnya. 


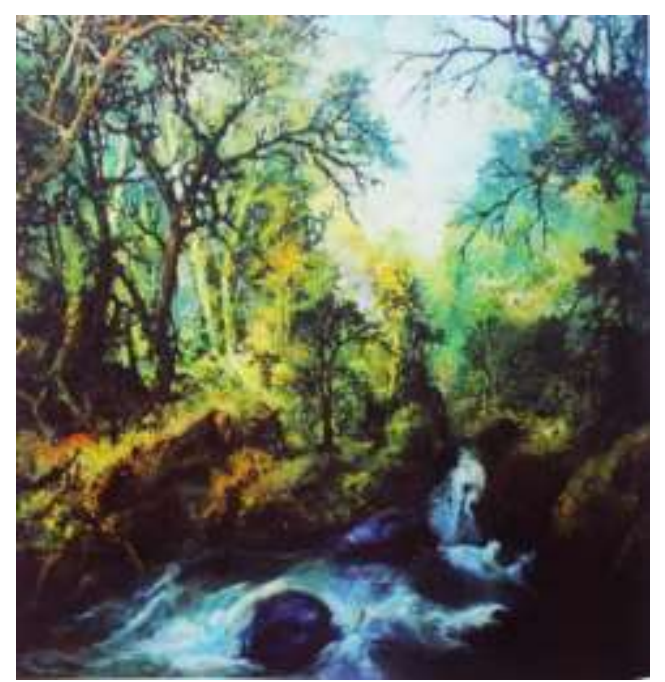

Gambar 1. Karya Afianto Arifin, "Sungai di Tengah Hutan", $74,5 \mathrm{~cm} \times 71 \mathrm{~cm}$, Oil on Canvas (Reproduksi: Selfina Rahmi, 2014)

\section{b. Gaya Susunan Formal}

Menurut Feldman, susunan formal ialah keseimbangan, harmoni, atau stabilitas di dalam seni yang diciptakan melalui aplikasi (penerapan) polapola ukuran yang metodis. Hal ini merupakan istilah lain dari "Klasikisme", yakni gaya klasik yang dapat ditemukan di semua zaman. Gaya susunan formal mengekspresikan kelebih-sukaan seniman terhadap keseimbangan dan stabilitas dalam karya kreatifnya, dan dengan implikasi, di dalam dunia secara menyeluruh (Feldman, 1967: 52). Hal tersebut juga tidak jauh berbeda dengan seni klasik Yunani yang di sana-sini memberikan kesempatan susunan formal bagi berbagai standar kesempurnaan keindahan dari gaya dinamis, gelora emosi, dan bentuk-bentuk gaya yang tidak stabil dari gaya Hellenistis. Hal yang sama, seni masa kini telah ditandai dengan gambar-gambar bergaya kekacauan dan kekerasan baik dengan rasionalitas maupun susunan.

Feldman membagi gaya susunan formal ini ke dalam beberapa variasi gaya yang dikarakterisasikan atau ditandai oleh stabilitas dan keabadian, yakni a) susunan intelektual, yakni susunan yang didasarkan pada berbagai pelaksanaan yang dijalankan oleh beberapa pikiran kita dengan reaksi-reaksi pengalaman sensoris yang pada gilirannya telah dirangsang oleh bahan visual yang diorganisasikan oleh seniman yang mengesankan intelektual dari kompleksitas matematis. b) susunan biomorfis, merupakan penciptaan susunan melalui pengorganisasian bentuk-bentuk yang didasarkan atas dunia biologis. Istilah "biomorfis" menunjukkan bentuk-bentuk artistik yang berkembang: melalui bagian sel-sel. c) susunan estetis, merupakan bukti gaya dalam karya-karya seni yang mencapai keseimbangan dan stabilitas semata-mata melalui pengorganisasian berbagai kualitas kenikmatan mereka. Susunan estetis tidak memerlukan percaya pada keakuratan, makna, atau referensi simbolis.

Salah satu karya Arifin yang berjudul "Di Pancuran III", memperlihatkan keseimbangan antara bentuk manusia dengan background alamnya, walaupun bentuk manusia dan alam tersebut tidak dilukiskan secara proporsional dan keakuratan yang matang. Lukisan tersebut menceritakan tentang aktivitas para perempuan Minangkabau yang memanfaatkan alam sebagai pemenuhan kebutuhan mereka akan air. Terlihat empat orang perempuan mengambil air di pancuran, yang satu sedang menaiki tangga, yang satunya lagi sedang menampung air, dan dua lainnya sedang memindahkan air ke dalam sebuah wajan belanga. Lukisan ini seakan memberikan pesan bahwa lingkungan alam yang terjaga kelestarian dan keseimbangannya akan memberi manfaat positif bagi sumber kehidupan manusia.

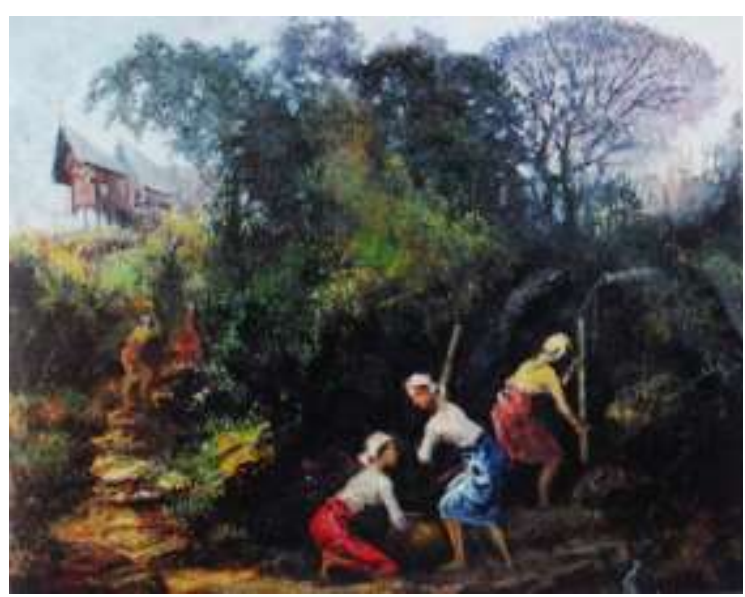

Gambar 2. Karya Afianto Arifin, "Di Pancuran III" $71 \mathrm{~cm}$ x $88 \mathrm{~cm}$, Oil on Canvas (Foto: Repro oleh Selfina Rahmi, 2014)

\section{c. Gaya Emosi}

Manusia menyadari bahwa sebagian besar kehidupan mereka memiliki emosi dan perasaan yang tidak dapat atau cenderung tidak diekspresikan (Feldman, 1967). Berangkat dari sini, mereka menyimpulkan bahwa fungsi utama seni rupa adalah menciptakan bentukbentuk yang tidak dapat terekam oleh kamera dan mengekspresikan berbagai perasaan yang mana tidak ada bahasa lain yang dapat ditemukan. Hal tersebut benar-benar meyakini bahwa seni di tengah-tengah benda lain adalah bahasa emosi.

Clive Bell berpendapat bahwa emosi yang dialami apabila menghayati karya seni adalah emosi yang tersendiri, dalam alam yang terasing. Hanya dengan cara ini karya seni dihayati dengan sempurna, bersih 
daripada nilai-nilai yang di luar aspek seni. Bell juga menyarankan, untuk menikmati sebuah karya seni, seseorang tidak sepatutnya dipengaruhi oleh pengalaman daripada alam harian. Keadaan ini selaras dengan proses penghasilan seni rupa yang dipindahkan dari alam biasa ke alam seni (Jamal, 1992).

Seniman menghasilkan karya atas dorongan untuk menyampaikan sesuatu melalui bahan, ide, dan emosi (Jamal, 1992: 11). Karya seni dapat menjadi perantaraan yang sempurna antara manusia. Bentuk objek seni itu sendiri, yang mempunyai unsur lain seperti ide, maklumat dan sebagainya menjadi nilai utama yang menentukan seni suatu karya.

Karya seni pasti memiliki gaya emosi, karena emosi berkaitan dengan ekspresi, perasaan dan hasil olah pikir seorang seniman. Tidak hanya lukisan ekspresif yang selalu diidentikkan dengan ekspresi dan emosi yang meluap-luap, karya Arifin yang naturalis-pun juga sarat dengan gaya emosi, seperti lukisan berjudul "Hujan", menceritakan tentang dua orang manusia yang terlihat satu tinggi dan satu pendek sedang berlari di tengah derasnya hujan. Terlihat dalam lukisan tersebut kumpulan awan kelam dengan keadaan hujan lebat yang membasahi pepohonan, tanah, dan rumah. Dari lukisan tersebut emosi yang muncul adalah emosi sedih, lalu suasana yang muncul adalah suasana suram yang dapat dirasakan dari warna yang cenderung gelap. Dari lukisan di bawah juga dapat disimpulkan bahwa Arifin melukiskan bentuk manusia, hujan dan alamnya dengan suasana emosi yang trenyuh dan sedih, seakan teringat akan masa lalu. Hal tersebut dapat kita lihat pada representasi objeknya yang menceritakan tentang dua orang bentuk manusia yang dilukiskan menggunakan warna gelap, meskipun persoalan bentuk tidak terlalu dikedepankan dalam lukisan tersebut. Melalui gaya emosi, Arifin bebas merepresentasikan bentuk dan ekspresi apa saja ke bidang kanvasnya, karena sejatinya sosok utama dari gaya emosi adalah keinginan nyata seniman untuk membuka tabir rahasia, bahkan untuk memparadokskan perasaannya seterang-terangnya dan sekuat mungkin (Feldman, 1967: 102-103).

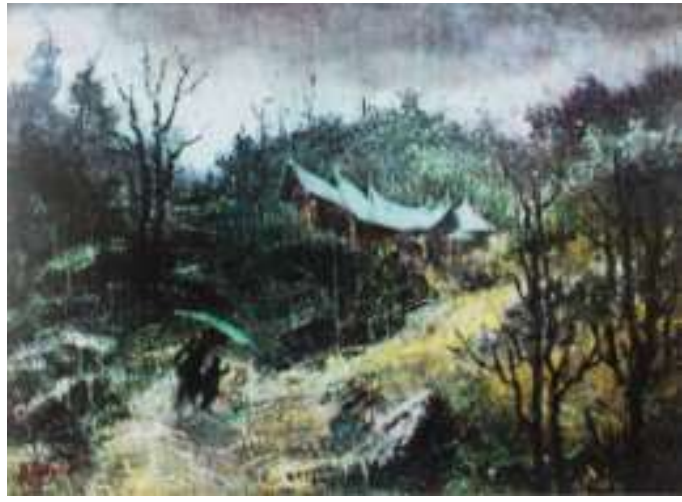

Gambar 3. Karya Afianto Arifin, "Hujan" $47 \mathrm{~cm}$ x $64 \mathrm{~cm}$, Oil on Canvas (Foto : Repro oleh Selfina Rahmi, 2014)

\section{d. Gaya Fantasi}

Feldman mengemukakan bahwa penciptaan fantasi merefleksikan persepsi seniman atas peranannya sebagai seorang yang menuruti pedoman, termasuk dalam kenyataan atau sebagai seorang yang mempunyai misi untuk mengubah aturan. Baik ia secara sengaja menciptakan bentuk-bentuk baru yang ganjil, logis dan dapat dipercaya ataukah ia membiarkan bentuk-bentuk fantasi terjadi menurut dirinya sendiri sebagai sebuah instrumen yang bekerja sama dengan berbagai proses penciptaan di dunia. Semua realitas penciptaan manusia adalah fantasi, tetapi semua fantasi tidak selalu menjadi realitas. Oleh karena seni fantastis menimbulkan kedua proses metal yang logis dan irasional, ia (seni fantastis) itu tidak menyajikan aturan umum kualitas visual. Karya-karya fantastis mungkin akurat secara objektif atau didistorsikan secara subjektif, teratur atau kacau, bergaris lurus atau lengkung. Karya-karya tertentu menunjukkan logika yang didasarkan atas pandangan halusinasi, mimpi, harapan utopian dan spekulasi (Feldman, Edmund, 1967: 129-133).

Gaya fantasi memberi kesempatan kepada para seniman untuk bebas menggunakan bahan-bahan mereka, sehingga para seniman tersebut menjadi terampil dan dapat menemukan bentuk-bentuk yang belum pernah dilihat atau diimajinasikan sebelumnya. Sementara hasil karya yang disajikan tentu tidak terlepas dari struktur dan kaidah unsur-unsur seni rupa yang ada.

Merujuk dari pernyataan di atas, Arifin adalah seorang pelukis studio dan umumnya karya-karya Arifin merupakan karya seni fantasi, yakni berdasarkan pengamatannya terhadap alam dan kehidupan manusia di sekitarnya yang dilukis di studio berdasarkan kekuatan imajinasinya sendiri. Sebagai contoh, karya bertemakan nude yang berjudul Wanita Mencuci- 
Mandi di Sungai, adalah karya hasil imajinasi Arifin sendiri yang bercerita tentang seorang perempuan setengah telanjang yang sedang mencuci di sungai. Terlihat perempuan tersebut tidak memakai baju dan memakai penutup kain hanya pada bagian pinggang hingga kakinya saja. Perempuan tersebut sedang mencuci kain berwarna merah di sungai yang mengalir airnya dan dikelilingi oleh pohon-pohon rimbun. Figur perempuan yang dilukiskan Arifin dan alam yang menjadi latar belakang dalam lukisan pun adalah hasil representasi objek (pikiran) Arifin sendiri terhadap fantasi 'alam'nya sendiri. Karya tersebut dapat kita lihat di bawah ini :

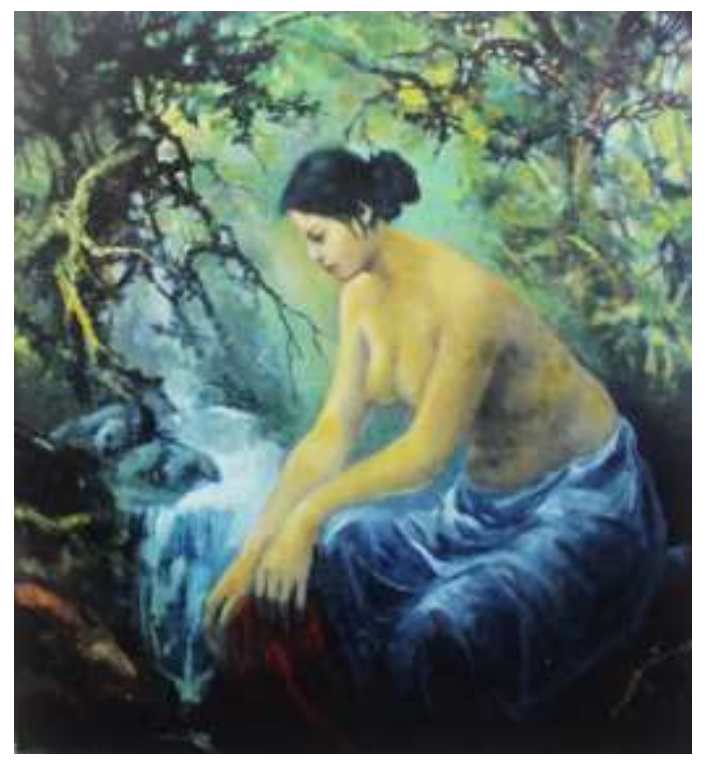

Gambar 4. Karya Afianto Arifin, "Wanita Mencuci - Mandi di Sungai"

$74,5 \mathrm{~cm} \times 68 \mathrm{~cm}$, oil on canva

(Foto : Repro oleh Selfina Rahmi, 2014)

Karya lukisan Arifin lainnya yang mencerminkan gaya fantasi juga dapat ditemukan pada karya yang berjudul "Angan-Angan seorang Wanita". Karya ini menceritakan tentang seorang gadis Minangkabau yang berangan-angan untuk menikah. Terlihat suasana murung dari ekspresi wajah si gadis yang duduk termenung memikirkan nasibnya yang entah kapan akan menikah. Arifin melukiskan perasaan si gadis dengan imajinasi bentuknya sendiri dan seakan ingin merepresentasikan perasaan murung si gadis lewat goresan-goresan yang spontan, bentuk anatomi tubuh si gadis pun tidak dilukis secara proporsional. Bentuk pasangan pengantin yang menjadi latar belakang dilukis agak kabur dan tidak terlalu jelas, seakan mewakili perasaan si gadis.

Arifin bebas mengekspresikan keinginan hatinya untuk melukiskan apa saja yang menjadi idenya untuk berkarya melalui karya seni, karena seni menguasai keinginan terhadap fantasi pada semua orang melalui "pengembangan" pada mimpi-mimpi, karena seniman melalui keahliannya, membuat mimpi dapat diraba, substansial, dan hidup (Feldman, Edmund, 1967: 131).

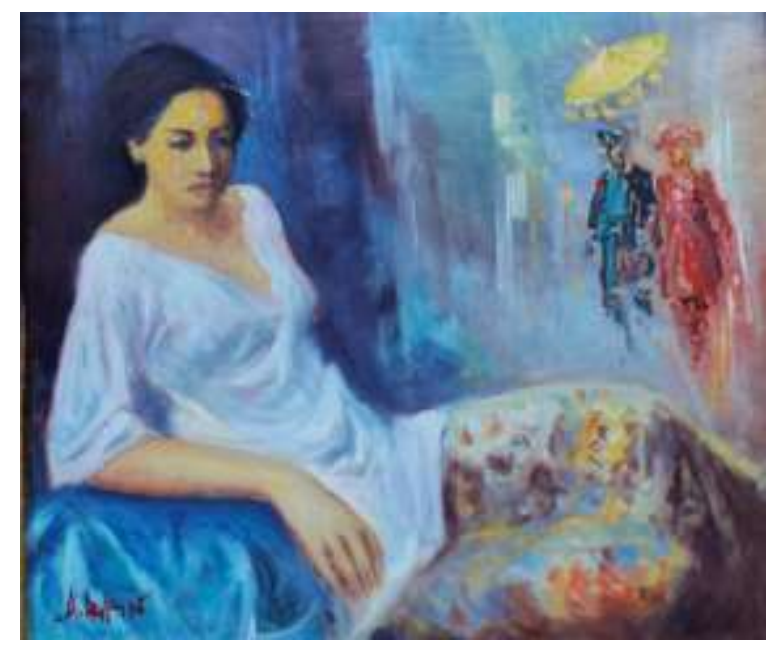

Gambar 5. Karya Afianto Arifin, "Angan-angan Seorang Wanita" $59 \mathrm{~cm}$ x $68 \mathrm{~cm}$, oil on canvas (Foto : Repro oleh Selfina Rahmi, 2014)

\section{Struktur Seni dalam Karya Seni Lukis Afianto Arifin}

Struktur atau susunan karya seni adalah aspek yang menyangkut keseluruhan dari karya itu dan meliputi juga peranan masing-masing bagian dalam keseluruhan itu. Struktur mengandung arti bahwa di dalam karya seni itu terdapat pengorganisasian, penataan; ada hubungan tertentu antara bagian-bagian yang tersusun itu. Akan tetapi dengan adanya penyusunan atau hubungan yang teratur antara bagianbagian, belumlah terjamin bahwa apa terwujud sebagai keseluruhan itu merupakan sesuatu yang indah, yang seni (Djelantik, 2004: 37). Guna memperoleh isyarat-isyarat pengoperasian dan tujuan dari objek, kita mesti melihat objek ke dalam bagianbagiannya. Tetapi, arti dari bagian-bagian karya seni selalu diarahkan oleh maknanya sebagai totalitas, yang mana totalitas adalah lebih penting daripada jumlah bagian-bagiannya (Feldman, 1967: 160). Kadangkadang, seni dibandingkan dengan bahasa visual, yakni ketika seseorang belajar memahami dengan mempelajari bagaimana setiap unsur dirangkai bersama. Feldman juga mengatakan bahwa dalam sebuah karya seni ada yang disebut dengan nilai-nilai formal atau sintaksis, yakni nilai-nilai yang dimotori oleh organisasi unsur-unsur visual dalam sebuah karya seni dan nilai tersebut mengangkat sumber kepuasan dan kesenangan tambahan. Dan untuk mengamati struktur seni yang ada pada karya Arifin, Feldman 
menawarkan pengamatan struktur seni melalui dua aspek berikut:

\section{a. Unsur-Unsur Visual: Kaidah (Grammar)}

Wujud gambar merupakan persepsi optis di dalam otak itu sendiri yang prosesnya berasal dari sinar yang masuk ke retina lalu dipindahkan sebagai energi yang mendorong otak dan secara simultan diterjemahkan ke dalam makna (Feldman, 1967). Dapat dikatakan otak mampu belajar memfokuskan perhatian terhadap bentuk, warna, tekstur, serta gelap-terang yang merupakan wujud dari gambar, dan ketika otak memfokuskan perhatian pada bagian dari unsur tersebut, maka ia akan menjadi wujud karena menjadi tempat kedudukan yang bermakna bagi kepentingan itu sendiri.

Pada karya lukis Arifin unsur garis sangat dominan dan bervariasi bentuknya. Ada garis panjang, pendek, halus, tebal, berombak, melengkung, dan lurus. Sedangkan untuk arahnya, Arifin mengombinasikan garis vertikal, horizontal dan diagonal dengan ukuran yang bersifat nisbi, yakni ukuran yang berupa panjang-pendek, tinggi rendah, besar-kecil, dan tebal tipis. Perpaduan garis-garis pada karya Arifin terkesan lebih ekspresif dan pada beberapa kasus, bentuk lukisan yang dihasilkan terkesan ekspresionis. Sungguh, pemanfaatan estetik garis jika pemanfaatan itu sangat ekspresif dan secara luas dibenarkan, dapat menjadi dasar kebiasaan-kebiasaan linear baru yang memudahkan orang mengenal dan memahami dengan segera.

Sebagai contoh, pada karya lukis Arifin berjudul "Pemandangan Alam II", unsur garis sangat mendominasi bentuk pemandangan alamnya. Terdapat banyak jenis garis, ada garis vertikal, horizontal, lengkung, pendek dan sebagainya, kesemuanya terbentuk oleh perpaduan warna yang menonjolkan bentuk alamnya. Arifin mendistorsi alamnya sendiri ke bidang kanvas dengan sentuhan naturalis yang sampai saat ini diyakininya.

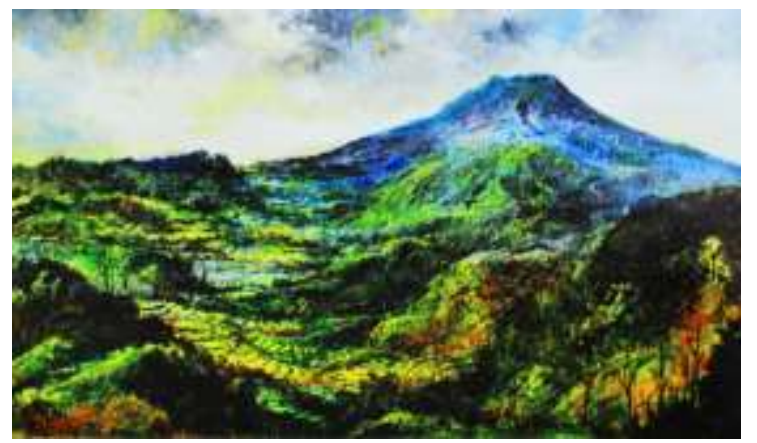

Gambar 6. Karya Afianto Arifin, "Pemandangan Alam II" $80 \times 134 \mathrm{~cm}$ oil on canvas
(Foto : Repro oleh Selfina Rahmi, 2014)

Selanjutnya, elemen visual lainnya yang terdapat dalam karya Arifin adalah warna. Peranan warna sangat dominan dalam karya seni rupa, hal ini dapat dikaitkan dengan upaya menyatakan gerak, jarak, tegangan (tension), deskripsi alam (dalam hal ini naturalisme), ruang, bentuk, ekspresi atau makna simbolik (Susanto, 2011: 433). Fungsi warna sebagai faktor yang menentukan (determinasi) bentuk dan memanfaatkan warna yang kita yakini akan menghasilkan emosi estetis (Feldman, 1967: 213).

Berdasarkan pembagiannya, warna tergolong atas warna primer (warna pokok), warna sekunder (warna jadian dari percampuran dua warna primer), warna intermediet (warna perantara yaitu warna yang ada di antara warna primer dan sekunder pada lingkaran warna), warna tersier (warna ketiga atau warna hasil percampuran dari dua warna sekunder), warna kuarter (warna keempat yaitu warna hasil percampuran dari dua warna tersier).

Berdasarkan tingkatannya, warna terdiri atas warna panas (warna yang dianggap menghasilkan kesan panas atau memiliki kualitas ke"terang"an yang kuat dibandingkan yang lain), warna dingin (warna yang dianggap menghasilkan kesan dingin), warna komplementer atau warna kontras (dua warna yang saling berseberangan 180 derajat pada lingkaran warna), warna lokal (kualitas (hue) warna yang dihasilkan pada permukaan benda dari cahaya kondisi normal), warna netral (warna yang dipersepsikan bukan sebagai warna: hitam, putih, dan abu-abu), dan warna optik (warna yang dipersepsikan sendiri oleh penonton, yang dapat disesuaikan dengan kondisi cahaya).

Dalam karya seni lukis Arifin, warna dimanfaatkan sebagai pembentuk objeknya. Arifin mengombinasikan warna panas dan warna dingin sebagai pembentuk gelap-terang dalam karyanya. Sebagai contoh, karya yang berjudul "Pemain Saluang dan Penyanyi”, warna panas digunakan sebagai cahaya terang, dan warna dingin dimanfaatkan sebagai pembentuk gelap-terang dalam karya tersebut. Warna panas dan warna dingin dikombinasikan membentuk perpaduan warna yang seimbang antara keduanya. Karya tersebut menceritakan tentang kesenian saluang dan dendang yang ada di Minangkabau. Terlihat seorang laki-laki sedang menghembus saluang yang duduk di antara dua orang perempuan. Salah seorang perempuan yang memakai baju merah sedang menyanyikan dendang, dan 
perempuan yang memakai baju kuning terlihat duduk mendampingi.

b. Organisasi dan Pengamatan Unsur-Unsur Estetik Organisasi visual merupakan organisasi yang mempunyai efektivitas lebih besar atau lebih kecil tergantung pada bagaimana baiknya unsur visualnya bekerja sama. Pengorganisasian unsur-unsur rupa meliputi kesatuan, keseimbangan, irama, proporsi, simetri, ritme (irama), dan harmoni atau keselarasan.

Unsur-unsur visual lain seperti keseimbangan, irama dan proporsi akan dilihat secara keseluruhan dalam satu kesatuan. Sebagai contoh, karya yang berjudul "Bukit Terkurung I", adalah lukisan pemandangan alam Ngarai Sianok yang ada di Bukittinggi dan dilukis di studio miliknya. Dengan tetap mengutamakan prinsip-prinsip seni rupa, lukisan tersebut tak jauh berbeda dengan objek sebenarnya dan lukisan tersebut merupakan hasil imajinasinya sendiri terhadap alam Ngarai Sianok yang telah diamati sebelumnya. Kesatuan seluruh elemen-elemen visual dapat dirasakan dalam karya tersebut. Keselarasan juga dapat dirasakan pada bentuk, ukuran, jarak dan warna yang saling mendukung satu sama lain. Arifin mampu menampilkan keseimbangan antara bentuk gunung dengan bukit serta lembah Ngarai Sianok-nya melalui permainan warna yang memberikan kesan bervolume. Warna yang diguratkan dalam karya, kesan yang muncul adalah suasana gersang dan kering, sangat kontras dengan keadaan alam Ngarai Sianok sebenarnya yang sejuk, indah dan subur. Arifin seakan ingin menyampaikan pesan agar tetap menjaga kelestarian alam ciptaan Tuhan, agar tidak rusak oleh tangan-tangan yang tidak bertanggung jawab.

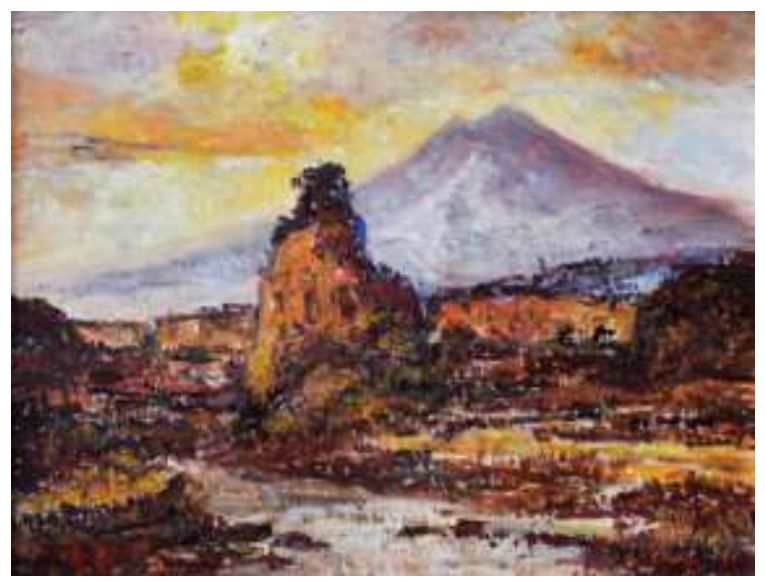

Gambar 7. Karya Afianto Arifin, "Bukit Terkurung I" $39 \mathrm{~cm} \times 51 \mathrm{~cm}$, oil on canvas (Foto : Repro oleh Selfina Rahmi, 2014)

\section{Interaksi Media dan Makna dalam Karya Seni Lukis Afianto Arifin}

Media merupakan bahasa pengantar yang dimanfaatkan untuk membentuk material menjadi bentuk artistik (Feldman, Edmund, 1967). Material tidak menyebabkan timbulnya kesulitan, material menunjukkan unsur-unsur fisik seni seperti cat, batu, kaca, tanah liat, dan logam. Feldman mengartikan media tidak hanya sebatas media berupa fisik, seperti cat, bahan perekat, sintetis, dan lain sebagainya. Namun, pengertian media lebih kepada penggunaan karakteristik dari bahan-bahan khusus untuk tujuan artistik. Untuk itu, dalam menelaah isi karya-karya lukisan Arifin, selain menilik dari segi interaksi media dan makna, terlebih dahulu akan ditinjau melalui segi tema-tema karya lukis Arifin. Feldman mengatakan bahwa pengalaman personal dalam proses penciptaan artistik diperlukan jika berbagai hubungan ini dimengerti sepenuhnya. Oleh karena itu, untuk menelaah lebih jauh tentang makna atau isi karya lukis Arifin, terlebih dahulu akan ditelusuri ide penciptaan karyanya.

a. Tema Karya Seni Lukis Afianto Arifin

Semua tema atau ide penciptaan karya lukis Arifin berangkat dari satu topik, yakni tentang Minangkabau, baik itu pemandangan alam (landscape), lukis wajah (potrait), lukisan alam dan manusia, kehidupan masyarakat Minangkabau, pernikahan dan adat istiadat, cerita atau legenda yang ada di Minangkabau, hingga lukisan yang bertemakan nude. Semua itu mencerminkan bahwa kehidupan Arifin dekat dengan kebudayaan dan adat istiadat yang ada di lingkungan tempat tinggalnya dan hal tersebut juga memperlihatkan bahwa Arifin adalah sosok yang peduli terhadap potensi dan keindahan yang ada di tanah tempat kelahirannya sendiri. Hal tersebut penting untuk dipahami, mengingat sosok Arifin adalah pribadi yang tegas, tak pelak hal tersebut juga akan mempengaruhi prinsip dan gaya berkeseniannya bahkan hingga saat sekarang ini.

Sebagai contoh pada karya lukis Arifin yang berjudul "Pengantin Bainai", menceritakan tentang adat istiadat yang ada di suku Minangkabau bahwasanya malam sebelum pernikahan, pengantin wanita diharuskan berhias kuku (bainai). Pada gambar terlihat seorang pengantin Minang dihias oleh empat orang wanita Minang lainnya, salah satunya sedang menghias kuku si pengantin. Arifin seakan ingin mengabadikan kebudayaan turun-temurun tersebut melalui bahasa visual, tentu dengan gaya naturalis-nya sendiri. 


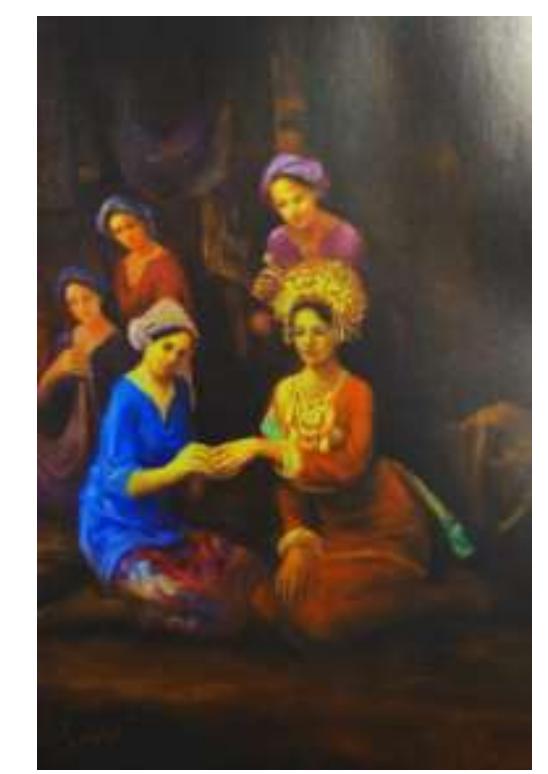

Gambar 8. Karya Afianto Arifin, "Pengantin Bainai" $120 \mathrm{~cm}$ x 80,5 cm, oil on canvas (Foto : Repro oleh Selfina Rahmi, 2014)

b. Isi atau Makna Karya Seni Lukis Afianto Arifin Tema-tema yang diangkat oleh Arifin ke dalam karyanya merupakan tema yang diilhami dari kehidupan masyarakat Minangkabau. Arifin menginterpretasikan hasil olah pikirnya ke dalam karya lukisan melalui gaya naturalis. Semenjak menapaki karier berkesenian, Arifin terus konsisten dengan satu gaya tersebut, bahkan hingga zaman postmodernisme saat sekarang. Namun bukan berarti Arifin kuat di satu gaya dan lemah di sisi lain, Arifin membuktikan kekonsistenannya dalam berkarya seni hingga sekarang ini. Bagi Arifin, naturalis adalah kunci untuk menguasai gaya lainnya.

Selanjutnya, dalam karya seni lukis lain yang berjudul "Mengantar Nasi", karya tersebut mengangkat cerita tentang kebiasaan masyarakat Minangkabau mengantar nasi untuk para petani yang bekerja saat musim panen tiba. Dalam lukisan tersebut, tampak dua orang bentuk wanita yang berjalan sambil membawa bakul makanan yang besar di atas kepala mereka. Dari lukisan tersebut, Arifin seakan ingin menampilkan nilai kegotong-royongan yang ada pada masyarakat Minangkabau, khususnya masyarakat pedesaan yang mana semakin jarang ditemukan pada masyarakat perkotaan, apalagi di zaman modern seperti sekarang. Arifin seolah-olah ingin menyampaikan kekhawatirannya tentang budaya asli masyarakat yang mulai luntur, akan tetapi bukan dengan bentuk-bentuk yang memberikan kesan memojokkan, namun ia menampilkannya dengan kesan positif yang memberikan suasana kerinduan akan sesuatu yang mulai hilang. Dari lukisan tersebut, tersirat bahwa
Arifin seolah ingin mengajak masyarakat untuk melestarikan kembali kebudayaan asli masyarakat yang mulai hilang akibat masuknya pengaruh zaman serba instan seperti sekarang melalui karya seni lukisnya.

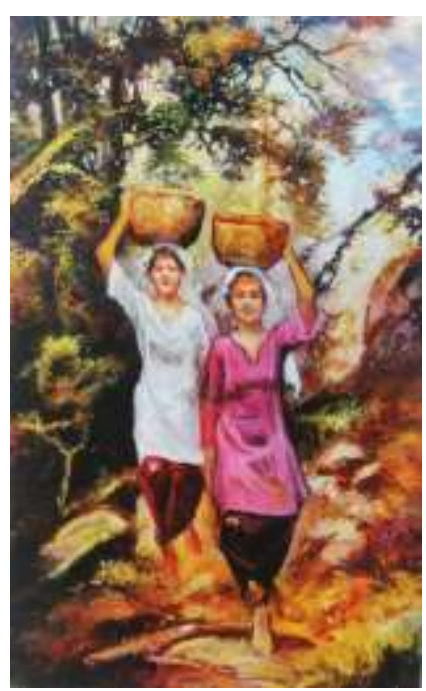

$$
\begin{gathered}
\text { Gambar 9. Karya Afianto Arifin, "Mengantar Nasi" } \\
45 \mathrm{~cm} \text { x } 60 \mathrm{~cm} \text {, oil on canvas } \\
\text { (Foto : Repro oleh Selfina Rahmi, 2014) }
\end{gathered}
$$

Arifin sering menggambarkan bentuk figur wanita dalam objek lukisannya. Hal tersebut bukanlah kebetulan, mengingat wanita adalah penyeimbang kehidupan, kehidupan tidak akan berlanjut tanpa adanya sosok wanita. Arifin menangkap filosofi tersebut terinspirasi dari peranan bundo kanduang di tengah-tengah kehidupan bermasyarakat suku Minangkabau. Bagi Arifin, banyak hal yang dapat diilhami dari sosok wanita, bahkan sosok wanita memberi pengaruh besar terhadap kualitas keturunannya nanti.

\section{KESIMPULAN DAN SARAN}

1.Kesimpulan

Pesona keindahan alam dan lingkungan tempat tinggal di kota Bukittinggi yang sarat akan adat-istiadat Minangkabau membuat Arifin tergugah untuk mengabadikannya ke dalam bentuk lukisan. Mulai dari lukisan alam dan manusia, landscape, hingga potrait laki-laki dan perempuan, Arifin selalu memberi sentuhan Minang di dalamnya. Di antaranya Arifin melukiskan legenda (kaba) Minang, seperti cerita Malin Kundang, Siti Nurbaya, Siti Jamilah, dan sebagainya. Selain itu, karya lukis Arifin juga terinspirasi dari lagu-lagu Minang, Cindua Mato, pasangan pengantin Minang, upacara baralek kawin, dan kaba. Selain dari karya lukis yang bertemakan Minang, karya lukis Arifin juga mengangkat perempuan bertemakan nude sebagai objek lukisannya karena kekagumannya akan kecantikan wanita. Karya- 
karya lukisan tersebut digarap dengan teknik tersendiri dan diakui sebagian kalangan memiliki ciri yang khas walaupun ditiru oleh sebagian orang.

Adapun konsep estetika yang dipakai dalam menganalisis karya lukis Afianto Arifin ini meliputi gaya-gaya seni berupa gaya ketepatan objektif, gaya susunan formal, gaya emosi dan gaya fantasi. Dilanjutkan dengan penganalisaan struktur karya seni lukis Arifin melalui pendekatan unsur-unsur visual, yakni garis, warna, tekstur, dan pendekatan organisasi pengamatan unsur-unsur estetik yakni kesatuan, keseimbangan, proporsi, simetri, ritme, dan harmoni atau keselarasan. Dan pada bagian terakhir ditelusuri interaksi media dan makna dalam karya seni lukis Arifin melalui tema dan makna karya lukisnya.

Bagi Arifin, hal yang menjadi utama saat sekarang ini ialah ingin meninggalkan coretan-coretan yang sempurna dan mewujudkannya ke dalam karya yang bisa dikenang dan menjadi sejarah bagi generasigenerasi selanjutnya, bahwa di masa sekarang seni rupa pernah ada, hidup dan berkembang, serta tengah memperjuangkan eksistensinya di kalangan hirukpikuk politik, ekonomi, dan lain sebagainya. Pada saat nanti, karya-karya Arifin diprediksi akan melambung tinggi dan namanya akan tercantum sebagai tonggak sejarah perkembangan seni rupa Sumatera Barat setelah era Wakidi.

\section{Saran}

Perkembangan seni rupa dan keberadaan seniman di Sumatera Barat khususnya di Bukittinggi hingga saat sekarang kurang mendapat dukungan dari pemerintah kota Bukittinggi. Hal tersebut hendaknya menjadi perhatian agar kesenian di kota Bukittinggi tidak hilang begitu saja.

\section{DAFTAR RUJUKAN}

A.A.M. Djelantik. (2004). Estetika Sebuah Pengantar. Bandung: Masyarakat Seni Pertunjukan Indonesia.

Arikunto, S. (1993). Prosedur Penelitian, Suatu Pendekatan Praktek. Edisi Revisi II. Jakarta: Anggota IKAPI, PT Rineka Cipta.

BECKER, H. S. (1982). Art World. Los Angeles; London; University of California Press; California University of California Press;

Feldman, Edmund, B. (1967). Art As Image and Idea, bagian dua, tiga, terjemahan SP.Gustami. New Jersey: Prentice-Hall.

Jamal, S. A. (1992). RUPA \& JIWA. Kuala Kuala Lumpur: Dewan Bahasa dan Pustaka,
Kementrian Pendidikan Malaysia.

Kartika, D. S. (2004). Pengantar Estetika. Bandung: Rekayasa Sains.

Kartodirjo, S. (1993). Pendekatan Ilmu Sosial dalam Metodologi Sejarah. Jakarta: PT Gramedia Pustaka Utama.

Prasetyo, B. (2005). Metode Penelitian Kualitatif Teori dan Aplikasi. Jakarta: Divisi Buku Perguruan Tinggi, PT. Raja Grafindo Persada.

Read, H. (1958). The Meaning Of Art, Terjemahan Soedarso, SP 1973. Yogyaakarta: ASRI.

Susanto, M. (2011). Diksi Rupa (1st ed.). Yogyakarta: DictiArt Lab. 